\title{
iPad-based Apps to Facilitate Communication in Critically Ill Patients with Impaired Ability to Communicate: A Preclinical Analysis
}

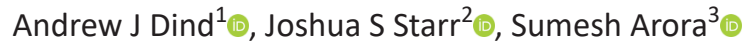

\begin{abstract}
Background: Inability to communicate is very distressing for patients in the intensive care unit (ICU). Most communication exchanges in ICU are initiated by healthcare workers (HCWs). Touch screen apps may enable patients to initiate communication and improve their interactions. Objectives: This study aimed to evaluate the pertinent features of iPad-based apps designed for communication in ICU.

Methods: Apple "App Store" and Google "Play Store" were searched for keywords "communication" and "intensive care." Related app suggestions were screened. Two independent assessors evaluated iPad-based apps that were deemed useful. The assessors resolved the discrepancies by re-evaluating the apps and reaching a consensus.

Results: Nine apps met the inclusion criteria. Of these six apps were free. There were seven apps specific to intensive care. Most apps had preloaded phrases for the patient to request to see someone (e.g., family), personal hygiene (e.g., bowel care), seek help with symptoms (e.g., pain), or a comfort item (e.g., blanket). CALD Assist, Patient Communicator, VidaTalk, and YoDoc were available in more than eight languages. VidaTalk and YoDoc allowed the user to write. Four apps were deemed not suitable for routine ICU use, while the remaining five had several attractive features.

Conclusion: Several high-quality apps are available to assist with patient-initiated communication exchange in ICU. This study provides a guide for readers to choose the app most suited to their needs. In the opinion of the authors, YoDoc is the most suitable app for routine use in ICU. Among free apps, CommuniCare appears to be the most user-friendly.

Keywords: Augmentative and alternative communication, Communication, Culture, Information and communication technology, Intensive care. Indian Journal of Critical Care Medicine (2021): 10.5005/jp-journals-10071-24019
\end{abstract}

\section{INTRODUCTION}

Effective communication with patients in the hospital improves both patient-reported and objective outcomes. ${ }^{1}$ As many as $40 \%$ of patients in the intensive care unit (ICU) report difficulties in communication., ${ }^{1,2}$ The reasons include endotracheal intubation, tracheostomy, requirement for noninvasive positive-pressure ventilation, head and neck surgery, stroke, sedation and sensory impairment, and inability to comprehend language spoken by healthcare workers ( $\mathrm{HCWs}$ ). ${ }^{3-6} \mathrm{~A}$ modern impediment to communication is the increased use, as a result of the coronavirus disease-2019 (COVID-19) pandemic, of personal protective equipment, which can impair communication by lowering voice volume, and by concealing lip movements, facial expressions, and name badges.

Up to $90 \%$ of the patients report extreme distress due to difficulty communicating, with associated anxiety, panic, anger, and sleeplessness. ${ }^{3,8,9}$ Inadequate communication may result in impaired symptom identification and participation of patients in management decisions.

Multiple augmentative and alternative communication (AAC) techniques, both unaided and aided, have been employed to improve interaction with ICU patients. Unaided AAC techniques, like lip reading, coded eye blinking, gesturing, and head nods, ${ }^{10,11}$ achieve limited patient and HCW satisfaction. Several basic patient needs, such as turning, suction, or requests to see other staff or family members, cannot be conveyed with unaided AAC. ${ }^{1,2,12,13}$ Aided AAC tools include "low-tech" interventions, such as pen and
${ }^{1-3}$ Department of Intensive Care Medicine, Prince of Wales Hospital, Sydney, New South Wales, Australia

Corresponding Author: Sumesh Arora, Department of Intensive Care Medicine, Prince of Wales Hospital, Sydney, New South Wales, Australia, Phone: +0434923831, e-mail: sumesharora1@gmail.com

How to cite this article: Dind AJ, Starr JS, Arora S. iPad-based Apps to Facilitate Communication in Critically III Patients with Impaired Ability to Communicate: A Preclinical Analysis. Indian J Crit Care Med 2021;25(11):1232-1240.

Source of support: Nil

Conflict of interest: Dr Arora is the Director of Quiz Time in Critical Care Pty Ltd, Sydney, Australia; which runs the website www. gotheextramile.com - MCQ in Critical Care. Dr Arora is not paid any salary for his work with Go the Extra Mile.

paper or communication boards, that have proved durable but are inefficient. ${ }^{14}$ Several "high-tech" interventions such as tablet-based app and eye-tracking software have now become available. ${ }^{10}$

Apps employ touch screen technology to expand on traditional talkboards and require little operator expertise..$^{10,11,13}$ These apps may facilitate nonverbal communication, which is patient-initiated, detailed, and critical care specific. There is emerging evidence that apps may improve communication and that patients will use them if they are available. ${ }^{15,16}$ However, there is little high-quality data regarding the features or relative efficacy of these communication apps. 5,10,17 
A good communication app for patients in ICU should be visually stimulating, but not distracting or cause information overload. It should have an adequate font size, good contrast, preloaded ICU-specific phrases (e.g., I need suction, I am in pain), and be available in multiple languages. ${ }^{18}$ This is a preclinical bench study aimed at evaluating various iPad-based communication apps specifically designed for use by patients in the ICU.

\section{Methods}

In November 2020, the "App Store" (Apple, Cupertino, California) and "Play Store" (Google, Mountain View, California) were searched with the keywords "Communication" and "Intensive Care." Related app suggestions were also screened to find further appropriate apps. The review of the apps is current as of May 7, 2021.

The inclusion criteria for further assessment of an app were that it was available on iPad in Australia and deemed helpful for communicating with ICU patients. Further details are available in Figure 1.

These apps were then assessed individually by two independent assessors through a preprepared electronic data collection form. Discrepancies between the two assessments were then resolved via a re-evaluation of the apps with the entire research team present.

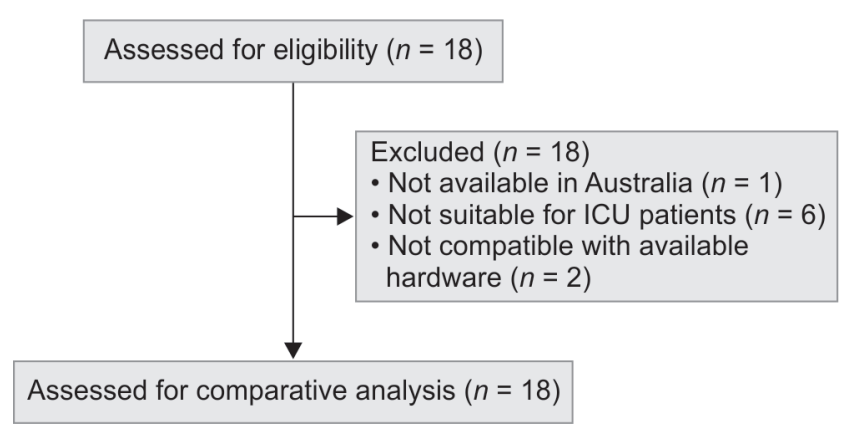

Fig. 1: Methodology of app selection
Data were collected using Google Forms with data stored on a password-protected Google Drive.

In accordance with the National Statement on Ethical Conduct in Human Research, this is a preclinical quality improvement initiative that does not involve any personal details; therefore, ethics approval was not sought. ${ }^{19}$

\section{Results}

The apps tested are listed in Table 1. In addition, two other apps were reviewed. "Hawkeye Access" (Hawkeye Labs, Inc., Alamo, California) tracks eye movements to help the user browse the Internet, and "I Have Voice (ALS, MND)" allows the user to communicate using eye gaze. Both apps are not ICU specific and cover relatively few needs for patients admitted to intensive care. We did not evaluate these apps further.

All apps worked on iPad and were compatible with Apple Pencil. All the apps were free except for YoDoc, which required a one-time payment of $\$ 14.99$ (Australian Dollars); AT Elements ICU, which cost \$1.49 (AUD); and VidaTalk, which cost \$169 (US Dollars), annually.

The availability of features relevant for ICU patients in different apps is listed in Table 2. All but two apps were ICU specific (CALD Assist and Talkboard-Communicator). The majority of the apps had preloaded phrases for the patient to request for personal hygiene. Only two apps allowed for the patients to write using their fingers or a stylus-VidaTalk and YoDoc.

The languages supported by various apps, requests available to see someone, and requests available for comfort items are listed in Table 3. Of note, CALD Assist, Patient Communicator, VidaTalk, and YoDoc were available in more than eight languages, potentially serving the needs of units that have culturally and linguistically diverse (CALD) group of admitted patients and HCW. Most of the apps contained a variety of preloaded phrases to see someone (family, doctor, nurse, physical therapist, etc.), for help with a symptom (pain, breathlessness, etc.) or comfort item (e.g., turn on the light, blanket).

Table 1: Publication specifics of apps reviewed

\begin{tabular}{|c|c|c|c|c|}
\hline App name (version*) & Apple platform (version) & Android platform & Publisher & $\begin{array}{l}\text { "App Privacy" details } \\
\text { on Apple App Store* }\end{array}$ \\
\hline $\begin{array}{l}\text { AT Elements ICU } \\
(2020)\end{array}$ & $\begin{array}{l}\text { iPad ( } 9.0 \text { or later) } \\
\text { iPhone ( } 9.0 \text { or later) }\end{array}$ & No & Alexicom Tech LLC (Phoenix, Arizona) & No \\
\hline $\begin{array}{l}\text { CALD Assist (culturally and } \\
\text { linguistically diverse) } \\
\text { (version 3.3) }\end{array}$ & $\begin{array}{l}\text { iPad ( } 12.0 \text { or later }) \\
\text { iPhone ( } 12.0 \text { or later) }\end{array}$ & Yes & $\begin{array}{l}\text { Commonwealth Scientific and Industrial } \\
\text { Research Organisation (CSIRO) } \\
\text { (Canberra, Australia) }\end{array}$ & No \\
\hline $\begin{array}{l}\text { CommuniCare ICU } \\
\text { (version 1.03) }\end{array}$ & iPad (9.0 or later) & No & CommuniCare OÜ (Tallinn, Estonia) & Yes \\
\hline $\begin{array}{l}\text { ICU Communication App } \\
\text { (version 2.0.7) }\end{array}$ & iPad (10.0 or later) & No & $\begin{array}{l}\text { Barnsley Hospital NHS Foundation Trust } \\
\text { (Barnsley, South Yorkshire) }\end{array}$ & Yes \\
\hline $\begin{array}{l}\text { Patient Communicator } \\
\text { (version 3.2.1) }\end{array}$ & $\begin{array}{l}\text { iPad ( } 10.0 \text { or later }) \\
\text { iPhone ( } 10.0 \text { or later) }\end{array}$ & Yes & $\begin{array}{l}\text { Society of Critical Care Medicine (Mount } \\
\text { Prospect, Illinois) }\end{array}$ & No \\
\hline $\begin{array}{l}\text { SmallTalk Intensive Care } \\
\text { (version 4.7) }\end{array}$ & $\begin{array}{l}\text { ¡Pad ( } 9.0 \text { or later) } \\
\text { ¡Phone ( } 9.0 \text { or later) }\end{array}$ & No & Lingraphica Inc. (Princeton, New Jersey) & Yes \\
\hline $\begin{array}{l}\text { Talkboard - Communicator } \\
\text { (2020) }\end{array}$ & $\begin{array}{l}\text { ¡Pad ( } 9.0 \text { or later) } \\
\text { iPhone ( } 9.0 \text { or later) }\end{array}$ & No & $\begin{array}{l}\text { Nikola Software LLC (San Francisco, } \\
\text { California) }\end{array}$ & No \\
\hline $\begin{array}{l}\text { VidaTalk } \\
\text { (version 3.0.5) }\end{array}$ & iPad (OS 10.0 or later) & No & Vidatak LLC (Annapolis, Maryland) & Yes \\
\hline $\begin{array}{l}\text { YoDoc } \\
\text { (version 2.2) }\end{array}$ & $\begin{array}{l}\text { iPad ( } 9.0 \text { or later) } \\
\text { iPhone ( } 9.0 \text { or later) }\end{array}$ & Yes & Docapps LLC (Bengaluru, India) & Yes \\
\hline
\end{tabular}

\footnotetext{
"Year of access" if version not available
} 
Four apps were deemed not suitable for routine ICU use. Some of the drawbacks of these apps that, in the opinion of the authors, make them unsuitable for routine ICU use are outlined in Table 4. The remaining apps had several attractive features, which we discuss below.

\section{Discussion}

There is emerging evidence that the use of AAC improves communication. ${ }^{15,16}$ However, at the time of publication, the use of apps to enhance communication is infrequent in ICUs. There are currently multiple apps available for communication in the ICU. Previous investigations have assessed the efficacy and usability of individual apps. ${ }^{20-25}$ However, there has been no direct comparison of apps to date. The results of this assessment will provide information to HCWs on app suitability for routine ICU use.
Communication needs vary among communities, and different apps may best serve their unique requirements. We will outline the salient feature of notable apps for routine ICU use.

AT Elements ICU (1.49 Australian Dollars) was found to have a clear layout (Fig. 2) with a high number of relevant preset phrases, including one of the largest collections of personal care requests. The app is highly customizable and, therefore, could be adjusted to fit specific communication requirements. The ability to convert typed text to speech is an important patient empowering feature. The accompanying images are small and of low quality, detracting from the overall usability, but could be customized if required. AT Elements did not provide a simple apparatus for the pain to be accurately localized or characterized and was only available in English.

CommuniCare (free) presented many easy-to-read preset phrases, which covered a majority of the requests common in the ICU. It had an uncluttered interface with clear images associated

Table 2: ICU-specific features of the apps tested

\begin{tabular}{|c|c|c|c|c|c|c|c|}
\hline App name & ICU specific & $\begin{array}{l}\text { Text easily } \\
\text { readable }\end{array}$ & $\begin{array}{c}\text { Number of } \\
\text { preset phrases }\end{array}$ & $\begin{array}{c}\text { Request for } \\
\text { personal hygiene }\end{array}$ & $\begin{array}{l}\text { Converts prewritten } \\
\text { text to speech }\end{array}$ & $\begin{array}{l}\text { Converts typed } \\
\text { text to speech }\end{array}$ & $\begin{array}{l}\text { Allows drawing } \\
\text { or scribble }\end{array}$ \\
\hline AT Elements ICU & $\checkmark$ & $\checkmark$ & $>100^{*}$ & $\checkmark$ & $\checkmark$ & $\checkmark$ & $x$ \\
\hline $\begin{array}{l}\text { CALD Assist (culturally and } \\
\text { linguistically diverse) }\end{array}$ & $x$ & $x$ & $>100$ & $x$ & $\checkmark$ & $x$ & $x$ \\
\hline CommuniCare ICU & $\checkmark$ & $\checkmark$ & $>100$ & $\checkmark$ & $\checkmark$ & $\checkmark$ & $x$ \\
\hline ICU Communication App & $\checkmark$ & $\checkmark$ & $0-50^{*}$ & $\checkmark$ & $\checkmark$ & $\checkmark$ & $x$ \\
\hline Patient Communicator & $\checkmark$ & $x$ & $0-50$ & $\checkmark$ & $x$ & $x$ & $x$ \\
\hline SmallTalk Intensive Care & $\checkmark$ & $\checkmark$ & $50-100$ & $\checkmark$ & $\checkmark$ & $x$ & $x$ \\
\hline Talkboard - Communicator & $x$ & $\checkmark$ & $0-50$ & $x$ & $x$ & $x$ & $x$ \\
\hline VidaTalk & $\checkmark$ & $x$ & $50-100$ & $\checkmark$ & $\checkmark$ & $\checkmark$ & $\checkmark$ \\
\hline YoDoc & $\checkmark$ & $\checkmark$ & $>100$ & $\checkmark$ & $\checkmark$ & $\checkmark$ & $\checkmark$ \\
\hline
\end{tabular}

*Offers the option to create new preset phrases

\begin{tabular}{lll}
\hline Alexicom pages & $\approx$ & $\lceil$ Edit \\
\hline SAD & & \\
\hline
\end{tabular}

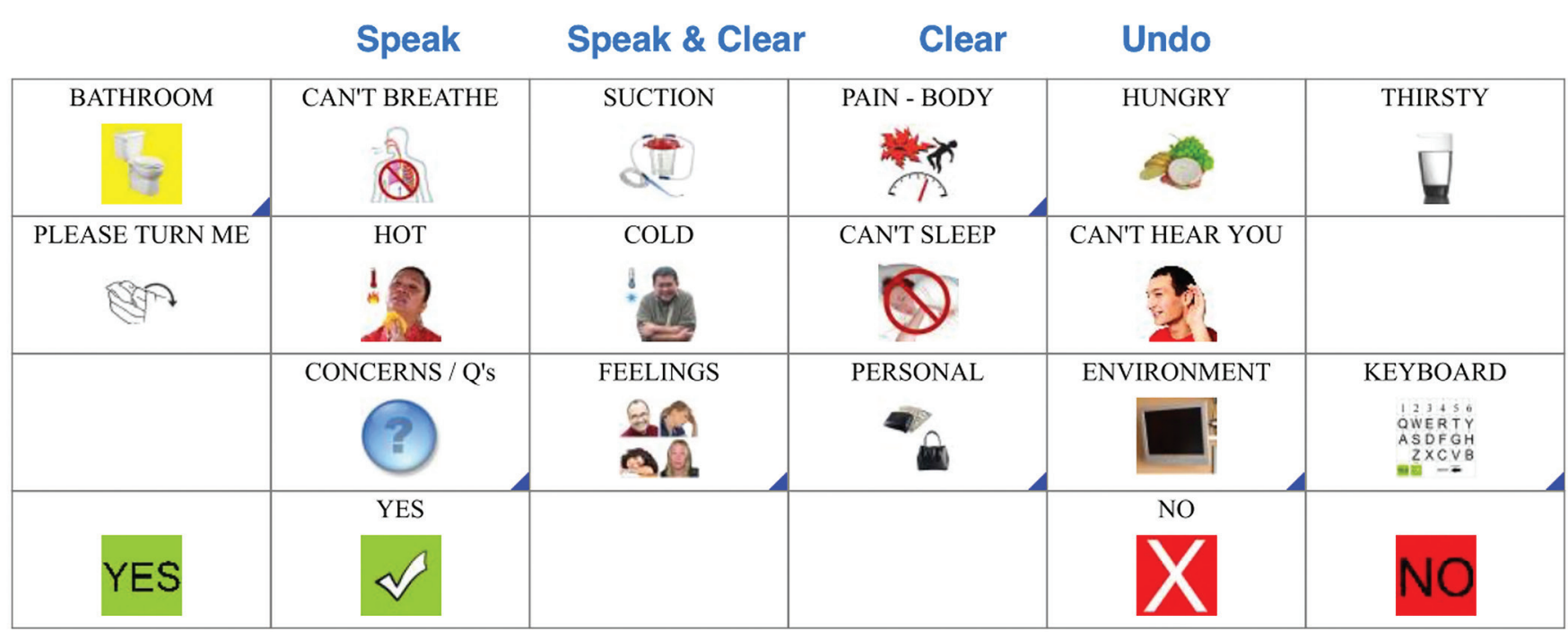

Fig. 2: App "AT Elements" with a screenshot of the available preset phrases 
Table 3: Multilanguage availability, request to see someone, and request for comfort items available in different apps

\begin{tabular}{|c|c|c|c|c|c|}
\hline \multirow{2}{*}{$\frac{\text { App name }}{\text { AT Elements ICU }}$} & \multicolumn{2}{|c|}{ Languages supported } & \multirow[b]{2}{*}{$\begin{array}{l}\text { Request to see someone } \\
\text { Doctor } \\
\text { Nurse } \\
\text { Family } \\
\text { Physiotherapist } \\
\text { Religious leader } \\
\text { Respiratory therapist }\end{array}$} & \multicolumn{2}{|c|}{ Personal care or comfort items } \\
\hline & English & & & $\begin{array}{l}\text { Analgesia } \\
\text { Bedpan } \\
\text { Dentures } \\
\text { Food } \\
\text { Glasses } \\
\text { Hearing aid } \\
\text { Lights on/off }\end{array}$ & $\begin{array}{l}\text { Phone } \\
\text { Suction } \\
\text { Turn } \\
\text { TV on/off } \\
\text { Urinary bottle } \\
\text { Wallet } \\
\text { Water }\end{array}$ \\
\hline CALD Assist & $\begin{array}{l}\text { Arabic } \\
\text { Cantonese } \\
\text { Croatian } \\
\text { English } \\
\text { Greek }\end{array}$ & $\begin{array}{l}\text { Italian } \\
\text { Macedonian } \\
\text { Mandarin } \\
\text { Serbian } \\
\text { Spanish } \\
\text { Vietnamese }\end{array}$ & Nil & Nil & \\
\hline CommuniCare ICU & $\begin{array}{l}\text { English } \\
\text { Estonian } \\
\text { Russian }\end{array}$ & & $\begin{array}{l}\text { Doctor } \\
\text { Nurse } \\
\text { Family } \\
\text { Physiotherapist } \\
\text { Religious leader } \\
\text { Respiratory therapist }\end{array}$ & $\begin{array}{l}\text { Bedpan } \\
\text { Lights on/off } \\
\text { Sleep } \\
\text { Analgesia } \\
\text { Blanket } \\
\text { Sedation } \\
\text { Positioning }\end{array}$ & $\begin{array}{l}\text { Medication } \\
\text { Urinary bottle } \\
\text { Suction } \\
\text { Ventilator } \\
\text { Pillow } \\
\text { Personal hygiene }\end{array}$ \\
\hline ICU Communication App & English & & $\begin{array}{l}\text { Doctor } \\
\text { Family }\end{array}$ & $\begin{array}{l}\text { Food } \\
\text { Water }\end{array}$ & $\begin{array}{l}\text { Toilet } \\
\text { Suction }\end{array}$ \\
\hline Patient Communicator & $\begin{array}{l}\text { Arabic } \\
\text { Chinese } \\
\text { Czech } \\
\text { Dutch } \\
\text { English } \\
\text { French } \\
\text { German } \\
\text { Hindi } \\
\text { Italian }\end{array}$ & $\begin{array}{l}\text { Lithuanian } \\
\text { Portuguese } \\
\text { Polish } \\
\text { Russian } \\
\text { Spanish } \\
\text { Swedish } \\
\text { Turkish } \\
\text { Urdu }\end{array}$ & $\begin{array}{l}\text { Doctor } \\
\text { Nurse } \\
\text { Family } \\
\text { Physical therapist } \\
\text { Religious leader }\end{array}$ & $\begin{array}{l}\text { Analgesia } \\
\text { Food } \\
\text { Wash }\end{array}$ & $\begin{array}{l}\text { Water } \\
\text { Restroom } \\
\text { Position }\end{array}$ \\
\hline SmallTalk Intensive Care & English & & $\begin{array}{l}\text { Doctor } \\
\text { Nurse } \\
\text { Physiotherapist } \\
\text { Respiratory therapist }\end{array}$ & $\begin{array}{l}\text { Analgesia } \\
\text { Antiemetic } \\
\text { Bedpan } \\
\text { Blanket } \\
\text { Brush teeth } \\
\text { Glasses } \\
\text { Hearing aid }\end{array}$ & $\begin{array}{l}\text { Lights on/off } \\
\text { Pillow } \\
\text { Suction } \\
\text { TV on/off } \\
\text { Urinary bottle } \\
\text { Water }\end{array}$ \\
\hline Talkboard - Communicator & $\begin{array}{l}\text { English } \\
\text { Spanish }\end{array}$ & & $\begin{array}{l}\text { Doctor } \\
\text { Family }\end{array}$ & $\begin{array}{l}\text { Blanket } \\
\text { Glasses, Lights off }\end{array}$ & $\begin{array}{l}\text { Pillow } \\
\text { Water }\end{array}$ \\
\hline VidaTalk & $\begin{array}{l}\text { Arabic } \\
\text { Bosnian } \\
\text { Chinese } \\
\text { Creole } \\
\text { English } \\
\text { Farsi } \\
\text { French } \\
\text { German } \\
\text { Hindi } \\
\text { Indonesian }\end{array}$ & $\begin{array}{l}\text { Italian } \\
\text { Japanese } \\
\text { Korean } \\
\text { Polish } \\
\text { Portuguese } \\
\text { Russian } \\
\text { Spanish } \\
\text { Tagalog } \\
\text { Vietnamese }\end{array}$ & $\begin{array}{l}\text { Doctor } \\
\text { Nurse } \\
\text { Family } \\
\text { Physiotherapist } \\
\text { Religious leader } \\
\text { Respiratory therapist } \\
\text { Social worker } \\
\text { Occupational therapist }\end{array}$ & $\begin{array}{l}\text { Analgesia } \\
\text { Bedpan } \\
\text { Blanket } \\
\text { Glasses } \\
\text { Hearing aid } \\
\text { Ice } \\
\text { Lights on/off } \\
\text { Phone call } \\
\text { Water }\end{array}$ & $\begin{array}{l}\text { Pillow } \\
\text { Suction } \\
\text { Positioning } \\
\text { TV on/off } \\
\text { Urinary bottle } \\
\text { Personal hygiene }\end{array}$ \\
\hline YoDoc & $\begin{array}{l}\text { Arabic } \\
\text { Armenian } \\
\text { Chinese } \\
\text { English } \\
\text { Farsi }\end{array}$ & $\begin{array}{l}\text { Hindi } \\
\text { Korean } \\
\text { Russian } \\
\text { Spanish }\end{array}$ & $\begin{array}{l}\text { Doctor } \\
\text { Nurse } \\
\text { Family } \\
\text { Occupational therapist } \\
\text { Pharmacist } \\
\text { Physiotherapist } \\
\text { Religious leader } \\
\text { Respiratory therapist } \\
\text { Social worker } \\
\text { Speech therapist }\end{array}$ & $\begin{array}{l}\text { Analgesia } \\
\text { Bedpan } \\
\text { Blanket } \\
\text { Glasses } \\
\text { Ice } \\
\text { Lights on/off } \\
\text { Pillow }\end{array}$ & $\begin{array}{l}\text { Suction } \\
\text { Turn in bed } \\
\text { TV on/off } \\
\text { Urinary bottle } \\
\text { Water }\end{array}$ \\
\hline
\end{tabular}


Table 4: Apps deemed relatively unsuitable for routine use in ICU

\begin{tabular}{|c|c|c|c|}
\hline & Name of app & Positive aspects & Drawbacks for routine ICU use \\
\hline 1 & CALD Assist & $\begin{array}{l}\text { Excellent app for the HCW to } \\
\text { communicate with the patients from } \\
\text { culturally and linguistically diverse } \\
\text { backgrounds }\end{array}$ & $\begin{array}{l}\text { - Small font size } \\
\text { - App not designed for patients to initiate the } \\
\text { conversation } \\
\text { - Not ICU specific } \\
\text { - Inability of patient to request for comfort items } \\
\text { - Inability of patients to request to see someone (e.g., } \\
\text { a family member) }\end{array}$ \\
\hline 2 & ICU Communication App & $\begin{array}{l}\text { The app allows for the addition of } \\
\text { phrases or words } \\
\text { With customization and appropriate } \\
\text { training, it may become a powerful } \\
\text { learning tool }\end{array}$ & $\begin{array}{l}\text { - Available only in English } \\
\text { - Absence of picture guide } \\
\text { - Not intuitive for patient use } \\
\text { - Limited preloaded phrases for comfort items } \\
\text { - Limited ability to assess pain }\end{array}$ \\
\hline 3 & SmallTalk Intensive Care & $\begin{array}{l}\text { Large, easy-to-read text with } \\
\text { intuitive pictures specific for ICU } \\
\text { patients. With some design improve- } \\
\text { ments, this app may potentially } \\
\text { become a useful communication tool }\end{array}$ & $\begin{array}{l}\text { - Available only in English } \\
\text { - All preloaded phrases available only on a single page } \\
\text { that needs to be scrolled up-down } \\
\text { - It may be difficult for ICU patient with limited concentrat- } \\
\text { ing ability to find the desired prewritten phrase }\end{array}$ \\
\hline 4 & Talkboard-Communicator & & $\begin{array}{l}\text { - Available only in English and Spanish } \\
\text { - Limited number of prewritten phrases } \\
\text { - Difficult to assess pain } \\
\text { - Limited preloaded phrases for comfort items }\end{array}$ \\
\hline
\end{tabular}

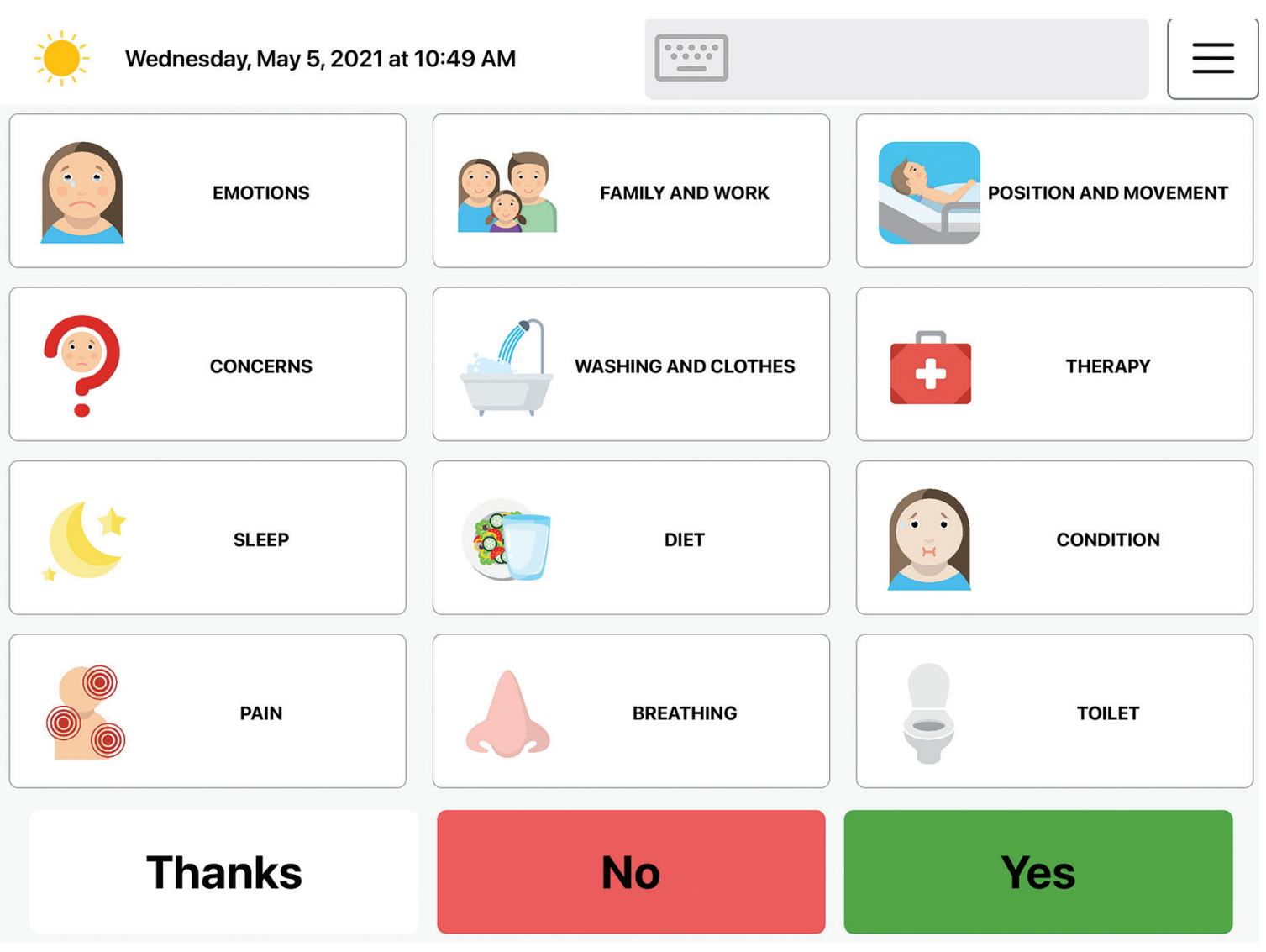

Fig. 3: App “CommuniCare ICU” homepage

with requests (Fig. 3). However, its primary limitation was its availability only in English, Russian, and Estonian. It also did not allow the user to draw or type words with a keyboard. Using its pain assessment tool, it was difficult to mark the site of pain.
Patient Communicator (free) is made available by the Society of Critical Care Medicine (USA). It had the highest number of languages (18) of any of the apps tested and had a good pain assessment feature (Fig. 4). It had additional features that may improve the 


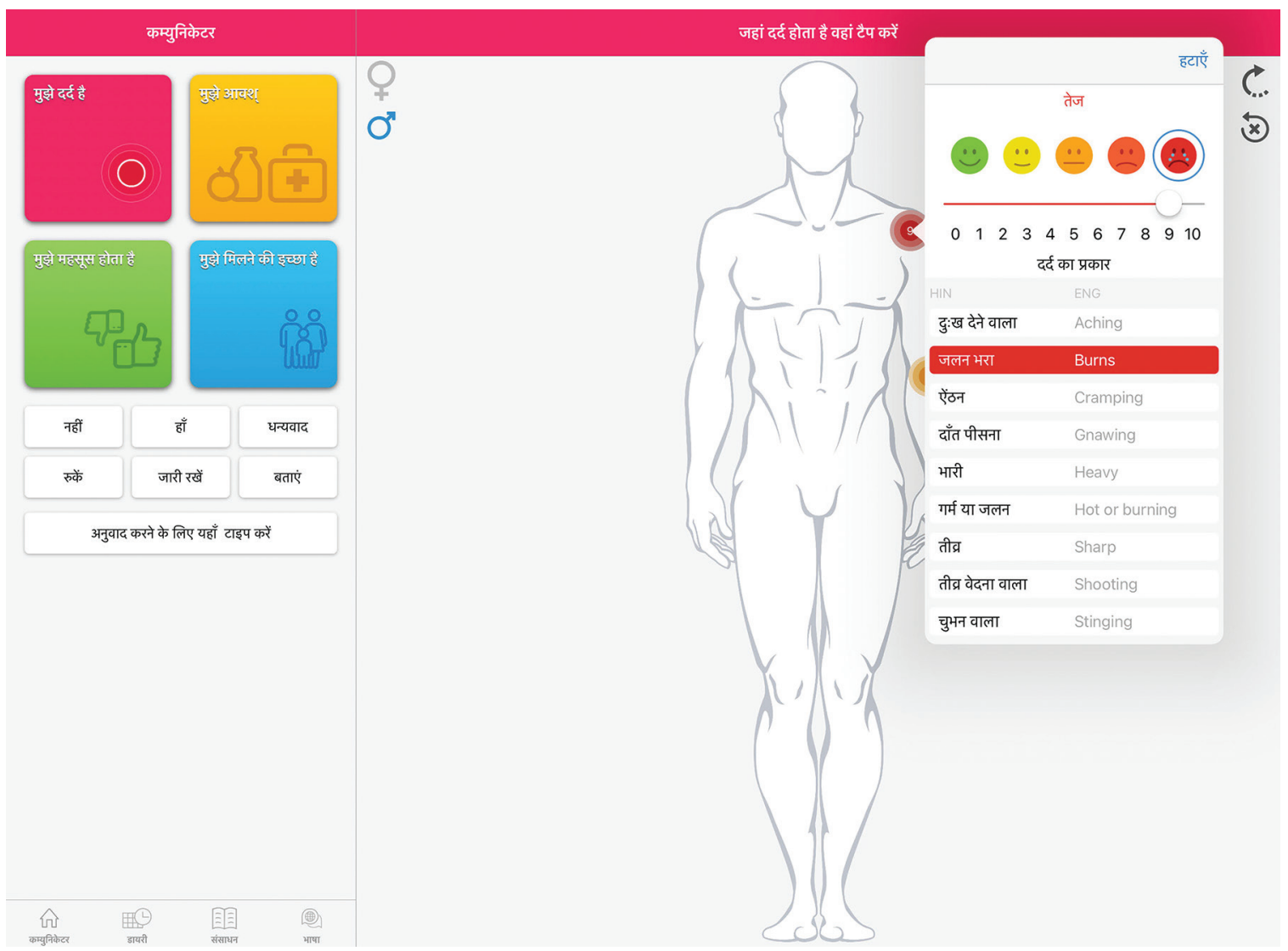

Fig. 4: App "Patient Communicator" by Society of Critical Care Medicine. This image demonstrates the pain assessment tool in Hindi. Other languages are available

care of long-term ICU patients, including a diary, glossary, and ICU stay booklet. The app lacked the ability to convert text to speech, limiting the feedback. Furthermore, the text size was smaller compared to other apps and deemed too small for practical use. There were no accompanying descriptive pictures with items of comfort or requests to see someone. It had very few preset requests, limiting patient-initiated communication exchange.

VidaTalk (USD 169 per annum) had many attractive features, including an extensive list of preset phrases relating to comfort, which are otherwise difficult to communicate nonverbally. The layout was straightforward, with clear, descriptive pictures, and it was also available in eight languages (Fig. 5). The tool for pain description was split across three tabs that may limit usability relative to other in-app tools. The text within VidaTalk is relatively small in size, which would likely not be suitable for patients with vision impairment. Furthermore, practical integration of the app in an ICU department requires consideration of cost vs its utilization. VidaTalk performed well at the point of analysis but was much more expensive when compared to other apps.

YoDoc (AUD 14.99) is translatable to nine languages (Fig. 6). The interface is stimulating without being distracting. YoDoc has been developed by Indian authors, and as such, the languages provided do not cover all the languages frequenting an Australian ICU. However, this was an issue with most of the apps assessed. The positive attributes of YoDoc are listed below:

- Intuitive and easy to use.

- User-friendly pain assessment tool (Fig. 7).
- Clear and informative pictures.

- Phrases can be organized by frequency of use.

- Adequate text size and contrast.

- Ninety-four preset spoken phrases.

- Allowance for typed words to convert to speech.

- Free text and drawing function.

Our study has several strengths. To our knowledge, this is the first study comparing the available ICU communication apps. Secondly, head-to-head comparisons of apps are difficult to make; however, we have provided a framework for these comparisons to be made (Tables 1 to 3 ).

Further, our study has several limitations. This is a bench study assessing the utility of an app prior to its implementation in the ICU. As a result, once an app is implemented, issues not previously noted will be identified and may change the app's usability in the future. The needs of specific communities and ICUs vary, and others may find different apps to be better suited to their requirements. It is likely that the demographics may play a role in acceptance. The acceptance may be higher in communities with higher awareness of technology, literacy, and if there is a cultural and linguistic divide between the HCW and patient population (e.g., an app may be useful for a non-English speaking patient in an Australian ICU, or vice versa).

In the opinion of the authors, YoDoc is the most suitable app for routine use in the ICU. Among free apps, CommuniCare appears to be the most user-friendly but is only available in English, Russian, and Estonian. The immediate future direction from this study is to introduce a communication app in the ICU 


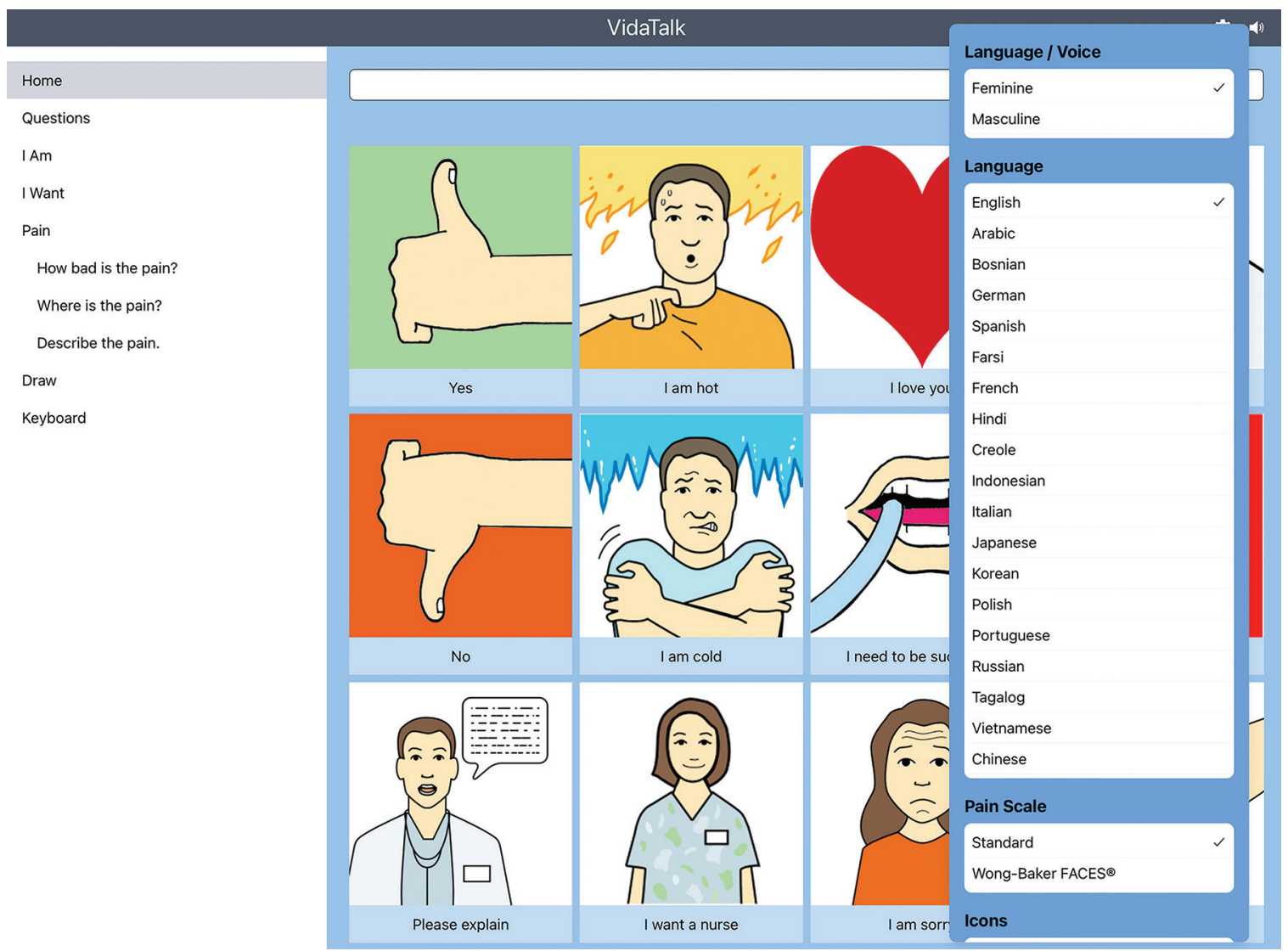

Fig. 5: App"VidaTalk." The side menu shows the list of languages available for use in patients from culturally and linguistically diverse backgrounds

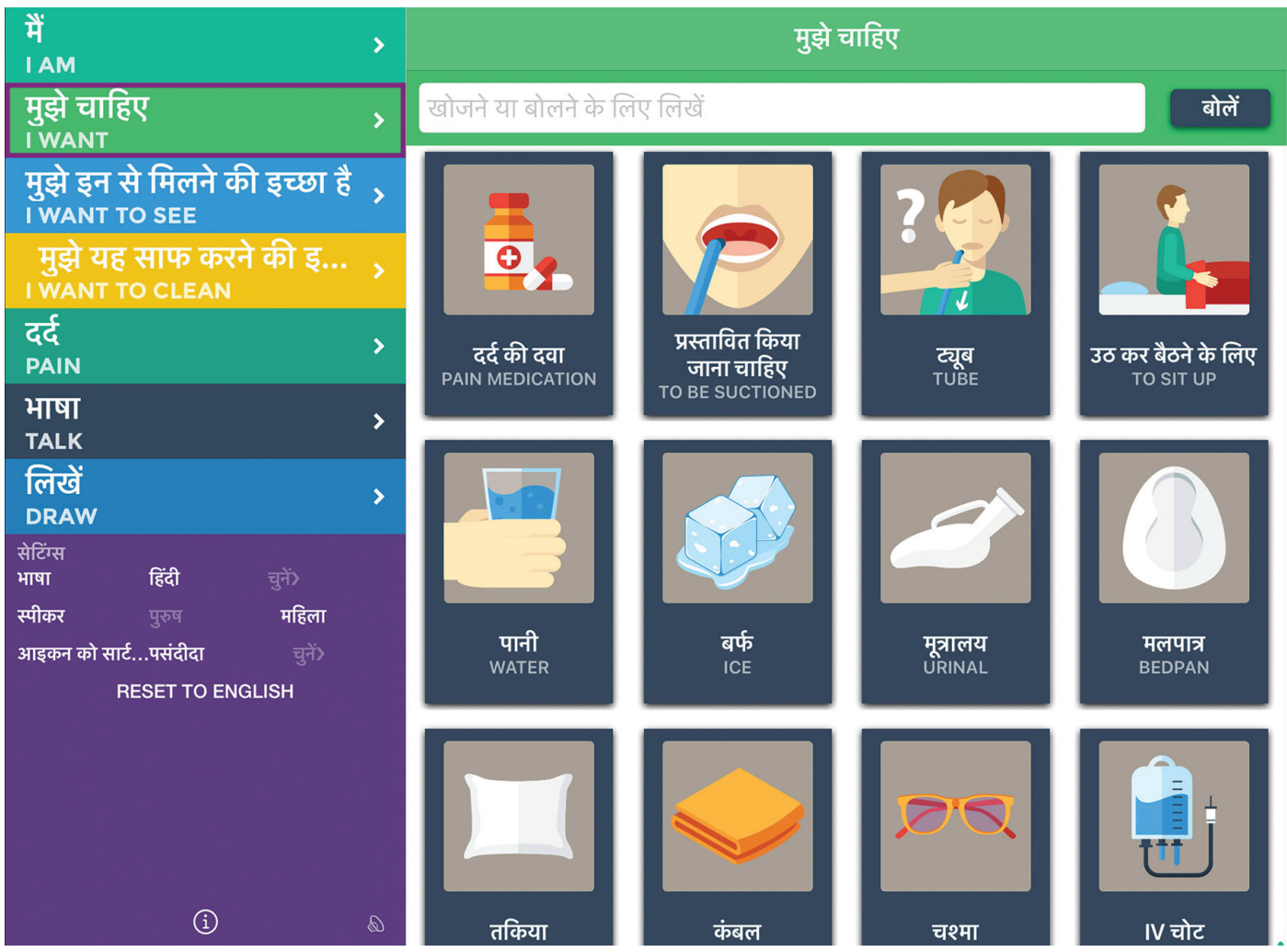

Fig. 6: App "YoDoc." The image shows preset phrases for comfort items, e.g., suction, written in both English and Hindi. More languages are available in this app 


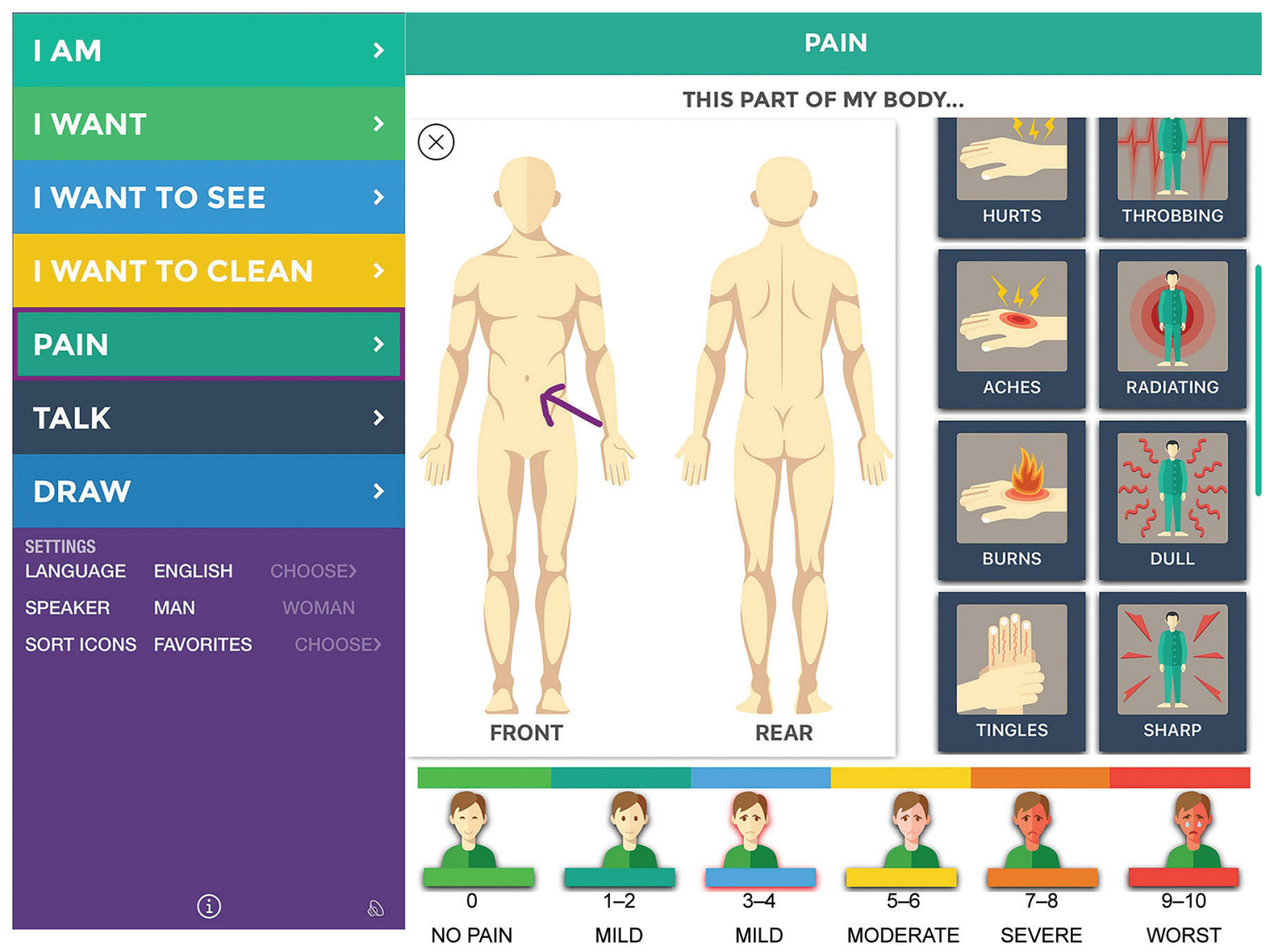

Fig. 7: App "YoDoc." This image shows the pain assessment tool. The arrow may be drawn by the patient to indicate the site of pain

and assess its effect on ease of communication, need for sedation, and incidence of delirium.

\section{Conclusion}

There are many high-quality apps available to assist with patientinitiated communication exchange in the ICU. These allow patients to make requests that would otherwise be difficult.

These apps make communication possible between HCWs and culturally and linguistically diverse patients. This study provides a guide for readers to choose the app most suited for their needs.

\section{ORCID}

Andrew J Dind $\odot$ https://orcid.org/0000-0003-4760-420X Joshua S Starr @ https://orcid.org/0000-0003-2449-1601 Sumesh Arora @ ittps://orcid.org/0000-0002-2065-3522

\section{References}

1. Happ MB, Garrett K, Thomas DDV, Tate J, George E, Houze M, et al. Nurse-patient communication interactions in the intensive care unit. Am J Crit Care 2011;20(2):e28-e40. DOI: 10.4037/ajcc2011433.

2. Carroll SM. Nonvocal ventilated patients' perceptions of being understood. West J Nurs Res 2004;26(1):85-103. DOI: $10.1177 / 0193945903259462$.

3. Khalaila R, Zbidat W, Anwar K, Bayya A, Linton DM, Sviri S. Communication difficulties and psychoemotional distress in patients receiving mechanical ventilation. Am J Crit Care 2011;20(6):470-479. DOI: 10.4037/ajcc2011989.

4. Albarran JW. A review of communication with intubated patients and those with tracheostomies within an intensive care environment. Intensive Care Nurs 1991;7(3):179-186. DOI: 10.1016/0266-612x(91)90007-e.

5. Mobasheri MH, King D, Judge S, Arshad F, Larsen M, Safarfashandi Z, et al. Communication aid requirements of intensive care unit patients with transient speech loss. AAC Augment Altern Commun 2016;32(4):261-271. DOI: 10.1080/07434618.2016.1235610.

6. White J, Plompen T, Osadnik C, Tao L, Micallef E, Haines T. The experience of interpreter access and language discordant clinical encounters in Australian health care: a mixed methods exploration. Int J Equity Health 2018;17:151. DOI: 10.1186/s12939-018-0865-2.

7. Freeman-Sanderson A, Rose L, Brodsky MB. Coronavirus disease 2019 (COVID-19) cuts ties with patients' outside world. Aust Crit Care 2020;33(5):397-398. DOI: 10.1016/j.aucc.2020.08.001.

8. Nelson JE, Meier DE, Litke A, Natale DA, Siegel RE, Morrison RS. The symptom burden of chronic critical illness. Crit Care Med 2004;32(7):1527-1534. DOI: 10.1097/01.ccm.0000129485.08835.5a.

9. Pennock BE, Crawshaw L, Maher T, Price T, Kaplan PD. Distressful events in the ICU as perceived by patients recovering from coronary artery bypass surgery. Hear Lung J Crit Care 1994;23(4):323-327. DOI: 10.4037/ajcc2019254.

10. Ten Hoorn S, Elbers PW, Girbes AR, Tuinman PR. Communicating with conscious and mechanically ventilated critically ill patients: a systematic review. Crit Care 2016;20(1):333. DOI: 10.1186/s13054-0161483-2.

11. Meltzer EC, Gallagher JJ, Suppes A, Fins JJ. Lip-reading and the ventilated patient. Crit Care Med 2012;40(5):1529-1531. DOI: 10.1097/ CCM.0b013e318241e56c. 
12. Broyles $L M$, Tate JA, Happ MB. Use of augmentative and alternative communication strategies by family members in the intensive care unit. Am J Crit Care 2012;21(2):e21-e32. DOI: 10.1049/ic:20000138.

13. Etchels MC, MacAulay F, Judson A, Ashraf S, Ricketts IW, Waller A, et al. ICU-talk: The development of a computerised communication aid for patients in ICU. Care Crit III 2003;19:4-9.

14. Nilsen ML, Morrison A, Lingler JH, Myers B, Johnson JT, Happ MB, et al. Evaluating the usability and acceptability of communication tools among older adults. J Gerontol Nurs 2018;44(9):30-39. DOI: 10.3928/00989134-20180808-07.

15. Happ MB, Garrett KL, Tate JA, DiVirgilio D, Houze MP, Demirci $J R$, et al. Effect of a multi-level intervention on nurse-patient communication in the intensive care unit: results of the SPEACS trial. Hear Lung J Acute Crit Care 2014;43(2):89-98. DOI: 10.1016/ j.hrtlng.2013.11.010.

16. Rodriguez CS, Rowe M, Thomas L, Shuster J, Koeppel B, Cairns P. Enhancing the communication of suddenly speechless critical care patients. Am J Crit Care 2016;25(3):e40-e47. DOI: 10.4037/ ajcc2016217.

17. Zaga CJ, Berney S, Vogel AP. The feasibility, utility, and safety of communication interventions with mechanically ventilated intensive care unit patients: a systematic review. Am J Speech-Language Pathol 2019;28(3):1335-1355. DOI: 10.1044/2019_AJSLP-19-0001.

18. Kuyler A, Johnson E. Patient and nurse content preferences for a communication board to facilitate dialogue in the intensive care unit. Intensive Crit Care Nurs 2021;63:103005. DOI: 10.1016/j. iccn.2020.103005.
19. NHMRC. National Statement on Ethical Conduct in Human Research, 2007 (Updated 2018). Australian Government: National Health and Medical Research Council; 2018.

20. Happ MB, Roesch TK, Garrett K. Electronic voice-output communication aids for temporarily nonspeaking patients in a medical intensive care unit: a feasibility study. Hear Lung J Acute Crit Care 2004;33(2):92-101. DOI: 10.1016/j.hrtlng.2003.12.005.

21. Happ MB, Roesch TK, Kagan SH. Patient communication following head and neck cancer surgery: a pilot study using electronic speechgenerating devices. Oncol Nurs Forum 2005;32(6):1179-1187. DOI: 10.1188/05.ONF.1179-1187.

22. Miglietta MA, Bochicchio G, Scalea TM. Computer-assisted communication for critically ill patients: a pilot study. J Trauma Inj Infect Crit Care 2004;57(3):488-493. DOI: 10.1097/01.ta. 0000141025.67192.d9.

23. Nilsen ML, Happ MB, Donovan H, Barnato A,Hoffman L, Sereika SM. Adaptation of a communication interaction behavior instrument for use in mechanically ventilated, nonvocal older adults. Nurs Res 2014;63(1):3-13. DOI: 10.1097/NNR.0000000000000012.

24. Rodriguez CS, Rowe M, Koeppel B, Thomas L, Troche MS, Paguio G. Development of a communication intervention to assist hospitalized suddenly speechless patients. Technol Heal Care 2012;20(6):489-500. DOI: 10.3233/THC-2012-0695.

25. Rodriguez C, Rowe M. Use of a speech-generating device for hospitalized postoperative patients with head and neck cancer experiencing speechlessness. Oncol Nurs Forum 2010;37(2):199-205. DOI: 10.1188/10.ONF.199-205. 